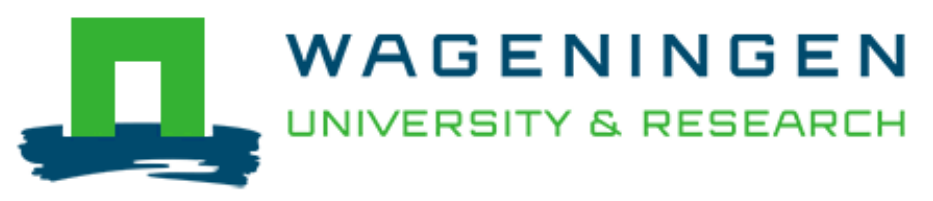

Modeling soil acidification in typical Chinese cropping systems

Zhu, Q., Liu, X., Hao, T., Zeng, M., Shen, J., Zhang, F., \& De Vries, W.

This is a "Post-Print" accepted manuscript, which has been published in "Science of the Total Environment"

This version is distributed under a non-commercial no derivatives Creative Commons (c) (1) $\theta \Theta$

(CC-BY-NC-ND) user license, which permits use, distribution, and reproduction in any medium, provided the original work is properly cited and not used for commercial purposes. Further, the restriction applies that if you remix, transform, or build upon the material, you may not distribute the modified material.

Please cite this publication as follows:

Zhu, Q., Liu, X., Hao, T., Zeng, M., Shen, J., Zhang, F., \& De Vries, W. (2018). Modeling soil acidification in typical Chinese cropping systems. Science of the Total Environment, 613-614, 1339-1348. DOI: 10.1016/j.scitotenv.2017.06.257

You can download the published version at:

https://doi.org/10.1016/j.scitotenv.2017.06.257 


\section{Modeling soil acidification in typical Chinese cropping systems}

Qichao Zhu ${ }^{1}$, Xuejun Liu$^{1}$, Tianxiang Hao ${ }^{1}$, Mufan Zeng ${ }^{1}$, Jianbo Shen ${ }^{1}$, Fusuo Zhang, ${ }^{1, *}$ Wim De Vries ${ }^{2,3, *}$

1 College of Resources and Environmental Sciences, Centre for Resources, Environment and Food Security, Key Lab of Plant-Soil Interactions, MOE, China Agricultural University, Beijing 100193, China

${ }^{2}$ Environmental Systems Analysis Group, Wageningen University, PO Box 47, 6700 AA Wageningen, The Netherlands

${ }^{3}$ Alterra-Wageningen UR, Soil Science Centre, P.O. Box 47, 6700 AA Wageningen, The Netherlands

${ }^{*}$ Corresponding authors

Fusuo Zhang ${ }^{1}$, Email: zhangfs@cau.edu.cn, Telephone: +86 10 62733499; Fax: +86 1062731016

Wim de Vries²,3, Email: wim.devries@wur.nl, Telephone: +31317486514; Fax: +31 317419000

The manuscript contains 6109 words (excluding references but including figures and tables) and 5 figures and 5 tables. 


\section{Abstract}

We applied the adapted model VSD+ to assess cropland acidification in four typical Chinese cropping systems (single Maize (M), Wheat-Maize (W-M), Wheat-Rice (W-R) and Rice-Rice (R-R)) on dominant soils in view of its potential threat to grain production. By considering the current situation and possible improvements in field (nutrient) management, five scenarios were designed: i) Business as usual (BAU); ii) No nitrogen (N) fertilizer increase after 2020 (N2020); iii) 100\% crop residues return to cropland (100\%RR); iv) manure $\mathrm{N}$ was applied to replace $30 \%$ of chemical $\mathrm{N}$ fertilizer (30\%MR) and v) Integrated N2020 and 30\%MR with 100\%RR after 2020 (INMR). Results illustrated that in the investigated calcareous soils, the calcium carbonate buffering system can keep pH at a high level for more than 150 years. In non-calcareous soils, a moderate to strong decline in both base saturation and $\mathrm{pH}$ is predicted for the coming decades in the BAU scenario. We predicted that approximately $13 \%$ of the considered croplands may suffer from Al toxicity in 2050 following the BAU scenario. The N2020, 100\%RR and 30\%MR scenarios reduce the acidification rates by $16 \%, 47 \%$ and $99 \%$, respectively, compared to BAU. INMR is the most effective strategy on reducing acidification and leads to no Al toxicity in croplands in 2050. Both improved manure and field management are required to manage acidification in wheat-maize cropping system. 


\section{Keywords}

Soil acidification; VSD+ model; cropland; scenarios; mitigation; China.

\section{Introduction}

Soil (water) acidification has received a lot of attention due to its negative impacts on the natural environment including fish dieback, nutrient imbalances in forest ecosystems and reduced plant species richness in natural ecosystems (Caputo et al., 2016; De Vries et al., 2015). Besides this, it can also affect agricultural production in croplands (Dai et al., 2017; Li et al., 2016; Mahler and McDole, 1987). Acidification accelerates the loss of base cations (i.e. $\mathrm{Ca}^{2+}, \mathrm{Mg}^{2+}, \mathrm{K}^{+}, \mathrm{Na}^{+}$), thus leading to soil fertility degradation (Zhang et al., 2015). At a (very) low pH, significantly elevated aluminum $\left(\mathrm{Al}^{3+}\right)$ and manganese $\left(\mathrm{Mn}^{2+}\right)$ releases can lead to high concentrations of these elements in soil solution, which in turn cause root damage and yield decline (Hue et al., 2001; Zhou, 2015). In addition, the concentration of heavy metals, especially cadmium $(\mathrm{Cd})$ and lead $(\mathrm{Pb})$ increase dramatically at low $\mathrm{pH}$ (De Vries and McLaughlin, 2013; De Vries et al., 2007), thereby accumulating in crops and in humans by bioaccumulation (Mok et al., 2015).

As the world's most populous country, China needs enough food supply via agricultural production. Continued growth in agricultural nutrient inputs have doubled China's grain yields both per-hectare and in total over the past decades (Liu et al., 2016; 
Vitousek et al., 2009). This helped to achieve a food self-sufficiency rate of more than 95\% in the first decade of this century (Qi et al., 2015). However, with this great achievement in crop production, China has suffered from significant acidification in its major croplands since the 1980 s, causing an averaged $0.5 \mathrm{pH}$ units decline due to excessive $\mathrm{N}$ fertilizer application (Guo et al., 2010). The acidification is expected to accelerate in the future because of increasing $\mathrm{N}$ fertilizer application and decreasing $\mathrm{N}$ use efficiency. Increased soil acidification, in combination with the urbanization induced arable land area reduction, could threaten the future food production in China. Insight in future impacts of field management on soil acidification can be gained with a soil acidification model, under the prerequisite that it is well validated on the long-term effects of agricultural practices on soil acidity. Until now, soil acidification models have hardly been applied to agricultural soils with the exception of the adapted VSD+ model (Bonten et al., 2016; Posch and Reinds, 2009) which has been shown to be able to reconstruct soil $\mathrm{pH}$ changes in long-term fertilization experiments (Zeng et al., 2017). We thus applied this model to assess long-term impacts of various fertilizer and land management scenarios on soil acidification of main cropping systems in China. We selected the VSD+ model also because it needs a limited set of input data and its fast simulation time for scenario analyses (Reinds et al., 2012).

Considering the important role of wheat, maize and rice in Chinese food supply, we focused the model analysis on the acidification of soil types below four typical 
cropping systems (single maize, wheat-maize, wheat-rice and rice-rice). The extended VSD+ model was applied to simulate the acidification in the period 1980-2010 and predict acidification trends in the period 2010-2050 for different scenarios showing the contributions of (i) reducing fertilizer $\mathrm{N}$ input, (ii) replacing $\mathrm{N}$ fertilizer by manure and (iii) reducing crop residue removal. The objective of the present work is to quantify the relative contribution of various strategies and propose the most promising and feasible combination of measures to mitigate soil acidification in the future.

\section{Materials and Methods}

\subsection{Model description}

The VSD+ (very simple dynamic) model is a single-layer dynamic model that consists of charge and mass balances to calculate changes in $\mathrm{pH}$ and element concentrations in soil solution and thereby element outputs from the root zone. The model was initially developed as the dynamic extension of a steady-state mass balance model for critical loads calculation, to calculate the effects of deposition on soil acidification and predict the effects of deposition abatement on European forest soils (Posch and Reinds, 2009). The extended version used in cropland was included in Zeng et al. (2017), which further includes the phosphate $\left(\mathrm{H}_{2} \mathrm{PO}_{4}{ }^{-}\right)$and sulfate $\left(\mathrm{SO}_{4}{ }^{2-}\right)$ removal in vegetation and soil adsorption-desorption.

The soil solution chemistry in VSD+ depends solely on the net element input 
(fertilizer, manure, fixation and deposition minus crop removal minus net immobilization) and the geochemical interactions in the soil $\left(\mathrm{CO}_{2}\right.$ equilibria, carbonates, silicates and/or Al hydroxides and cation exchange). Soil interactions are either described by simple rate-limited (zero-order) reactions (uptake and base cation weathering) or by equilibrium reactions (carbonate and Al hydroxide dissolution and cation exchange). Solute transport is described by assuming complete mixing of the net element input in one homogeneous soil compartment with a constant density and a fixed depth (root zone). The annual water flux percolating from this layer is taken equal to the annual precipitation surplus that is assumed constant during the model runs (steady-state hydrology). The time step of the model is one year, so seasonal variations are not considered. An overview of the included rate limited and equilibrium reactions and used process descriptions is given in Table 1. The explicit description on those process descriptions can be found in Posch and Reinds (2009) and Bonten et al. (2016).

Table 1 . The rate limited and equilibrium reactions and related process descriptions included in the extended VSD + model. $(\mathrm{BC}=\mathrm{Ca}+\mathrm{Mg}+\mathrm{K}+\mathrm{Na})$

\begin{tabular}{|c|c|c|c|}
\hline Reactions & Element & Process description & $\begin{array}{l}\text { Relevant } \\
\text { parameter }\end{array}$ \\
\hline \multicolumn{4}{|c|}{ Rate-limited reactions } \\
\hline Growth uptake & $\begin{array}{l}\mathrm{N}, \mathrm{P}, \mathrm{S} \\
\mathrm{BC}\end{array}$ & Yield times N content & X_upt \\
\hline $\mathrm{N}$ immobilization & $\mathrm{N}$ & Roth C model approach & rf_min \\
\hline Nitrification & $\mathrm{N}$ & $\begin{array}{l}\text { Proportional to net } \mathrm{NH}_{4} \\
\text { input }\end{array}$ & rf_nit \\
\hline
\end{tabular}




\begin{tabular}{|c|c|c|c|}
\hline Denitrification & $\mathrm{N}$ & $\begin{array}{l}\text { Proportional to net } \mathrm{NO}_{3} \\
\text { input }\end{array}$ & rf_denit \\
\hline Silicate weathering & $\mathrm{BC}$ & $\begin{array}{l}\text { Zero order reaction (constant } \\
\text { rate depending on soil type) }\end{array}$ & BC_we \\
\hline \multicolumn{4}{|l|}{ Equilibrium reactions } \\
\hline $\begin{array}{l}\text { Dissociation of } \\
\text { bicarbonate }\end{array}$ & $\mathrm{HCO}_{3}$ & $\mathrm{CO}_{2}$ equilibrium equation & $\mathrm{KCO}_{2}$ \\
\hline $\begin{array}{l}\text { Dissociation of } \\
\text { organic acids }\end{array}$ & $\mathrm{C}$ & Oliver model & Korg \\
\hline Cation exchange & $\mathrm{H}, \mathrm{BC}, \mathrm{Al}$ & $\begin{array}{l}\text { Gapon equation } \\
\text { /Gaines-Thomas equation }\end{array}$ & $\begin{array}{l}\operatorname{lgKAlBC} \\
\operatorname{lgKHBC}\end{array}$ \\
\hline $\begin{array}{l}\text { Dissolution of Al } \\
\text { hydroxides }\end{array}$ & $\mathrm{Al}$ & Gibbsite equilibrium & lgKAlox \\
\hline Adsorption-desorption & $\mathrm{P}, \mathrm{S}$ & Langmuir isotherm & $\begin{array}{l}\text { PO4admax, } \mathrm{PO}_{\text {half }} \\
\text { SO4 } 4 \text { admax } \mathrm{SO}_{\text {half }}\end{array}$ \\
\hline
\end{tabular}

2.2 Application methodology and data assessment

The modelling assessment was carried out for the period 1980-2050, including available datasets on element inputs and crop uptake for the period 1980-2010 and scenarios for inputs and uptake for the period 2010-2050. The study was focused on the acidification of typical grain cropping systems, including single season maize (M), wheat-maize (W-M), wheat-rice (W-R) and rice-rice (R-R), on dominant soil types. To gain insight into the area of combinations of soils and cropping systems, an overlay was made by ArcGIS (ESRI, USA) of a digital map of land use, using the Multi-source Integrated Chinese Land Cover map (Ran et al., 2012), and of soil types, using the Harmonized World Soil Data map (HWSD version 1.1, Fischer et al., 2008). Since the land use map did not give information on crop types, we assumed that one cropping 
system dominates in each province. The map of this cropping system distributions is shown in Fig. 1.

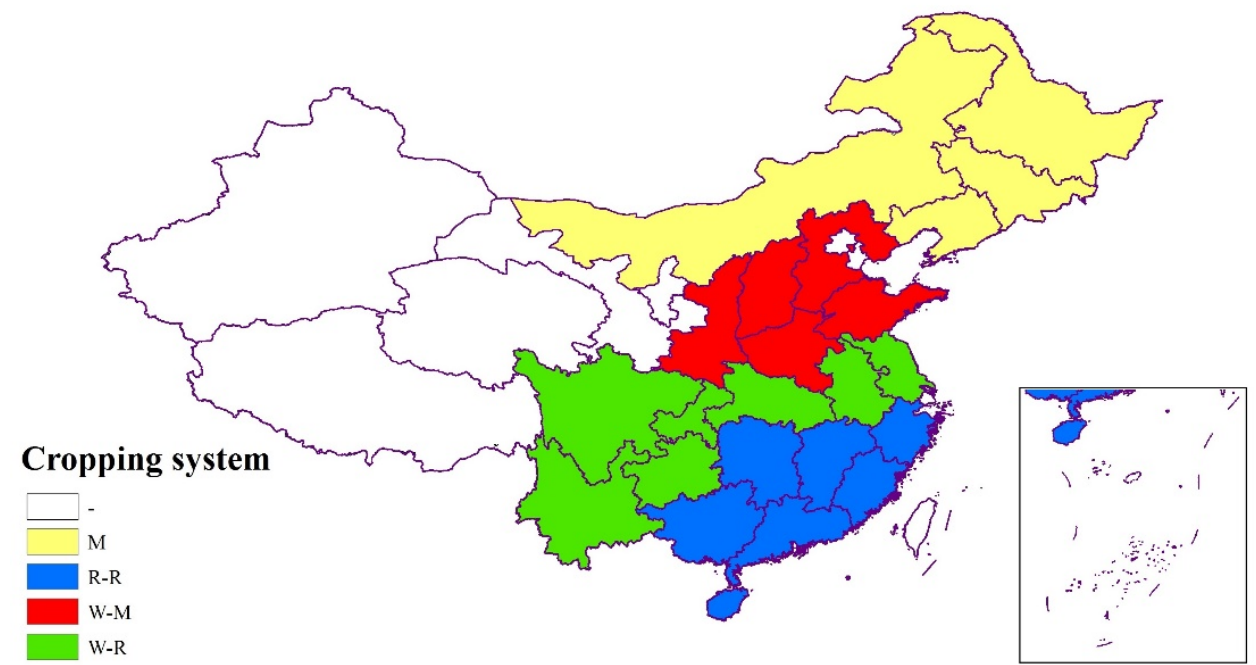

Fig. 1 Distribution of the considered dominant cropping systems in China. M, R-R, W-M, W-R denote the single maize, rice-rice, wheat-maize and wheat-rice cropping systems, respectively.

The three soil types with the largest area of croplands in each cropping system were then selected. Eventually, twelve combinations (four cropping systems $\times$ three soil types) were chosen in the assessment, which represent $54.6 \%$ of the total Chinese croplands, as shown in Table 2. 
Table 2 Area of dominating soil types in percentage of total arable land

\begin{tabular}{ccccc}
\hline Cropping system & $\begin{array}{c}\text { Carbonates } \\
\text { in soil }\end{array}$ & Soil type & $\begin{array}{c}\text { Area } \\
\left(10^{6} \text { ha) }\right)\end{array}$ & $\begin{array}{c}\text { Ratio to area of } \\
\text { total arable land } \\
\text { in China (\%) }\end{array}$ \\
\hline M & No & Phaeozem (PH) & 7.8 & $\mathbf{6 . 0}$ \\
M & No & Luvisols (LV) & 5.5 & $\mathbf{4 . 2}$ \\
M & Yes & Cambisols (CM-Ca) & 2.6 & 2.0 \\
W-M & Yes & Cambisols (CM-Ca) & 9.7 & 7.4 \\
W-M & Yes & Fluvisol (FL) & 9.5 & 7.3 \\
W-M & No & Luvisols (LV & 3.9 & 3.0 \\
W-R & Yes & Anthrosols (AT) & 7.9 & 6.0 \\
W-R & No & Cambisols (CM) & 6.0 & $\mathbf{4 . 6}$ \\
W-R & Yes & Fluvisol (FL) & 5.0 & 3.9 \\
R-R & Yes & Anthrosols (AT) & 5.6 & 4.3 \\
R-R & No & Acrisols (AC) & 5.6 & $\mathbf{4 . 3}$ \\
R-R & No & Cambisols (CM) & 2.1 & $\mathbf{1 . 6}$ \\
Total & & - & 70.9 & $54.6 \%$ \\
\hline
\end{tabular}

${ }^{1}$ The total area of arable land in China is $1.3 \times 10^{8}$ ha. Note that the area of non-calcareous soils below grain crops is $23.7 \%$ and the remaining $30.9 \%$ is calcareous.

Data required to run VSD+ was grouped into input fluxes, output fluxes, soil properties and parameters and meteorological data. The assessment of these datasets is described below and summarized in Table 3. Details on the derivation of the various parameters are given in the Supplementary material 
Table 3. List of symbols and data sources of input-output fluxes soil properties, model parameter and meteorological data used in VSD+ and MetHyd.

\begin{tabular}{|c|c|c|c|}
\hline Data used & Explanation & Unit & Data sources \\
\hline \multicolumn{4}{|l|}{ Input fluxes } \\
\hline X_dep ${ }^{1}$ & Input by deposition & eq $\mathrm{m}^{-2} \mathrm{yr}^{-1}$ & $\begin{array}{l}\text { Zhu et al. } \\
\text { (submitted) }^{2}\end{array}$ \\
\hline X_frt & Input by fertilization & eq $\mathrm{m}^{-2} \mathrm{yr}^{-1}$ & $\begin{array}{l}\text { Zhu et al. } \\
\text { (submitted) }\end{array}$ \\
\hline Nfix & $\mathrm{N}$ fixation & eq $\mathrm{m}^{-2} \mathrm{yr}^{-1}$ & $\begin{array}{l}\text { Zhu et al. } \\
\text { (submitted) }\end{array}$ \\
\hline $\begin{array}{l}\text { BC_we } \\
\text { Output fluxes }\end{array}$ & Weathering rate of $\mathrm{BC}(\mathrm{K}, \mathrm{Na}, \mathrm{Ca}, \mathrm{Mg})$ & eq $\mathrm{m}^{-2} \mathrm{yr}^{-1}$ & Duan (2000) \\
\hline X_upt & $\begin{array}{l}\text { Yearly net removal of } \mathrm{X} \text { from the soil } \\
\text { by harvest }\end{array}$ & eq $\mathrm{m}^{-2} \mathrm{yr}^{-1}$ & $\begin{array}{l}\text { Zhu et al. } \\
\text { (submitted) }\end{array}$ \\
\hline \multicolumn{4}{|c|}{ Soil properties } \\
\hline Thick & Thickness of the soil compartment & $\mathrm{m}$ & Root zone ${ }^{3}$ \\
\hline$p \mathrm{CO}_{2 \mathrm{fac}}$ & $\begin{array}{l}\mathrm{CO}_{2} \text { pressure in the soil solution } \\
\text { divided to the pressure in atmosphere }\end{array}$ & - & $\begin{array}{l}\text { Nan et al. } \\
(2016)\end{array}$ \\
\hline bulk dens & Average bulk density of the soil & $\mathrm{g} \mathrm{cm}^{-3}$ & $\mathrm{HWSD}^{4}$ \\
\hline CEC & Cation exchange capacity of the soil & meq kg-1 & HWSD \\
\hline Bsat_0 & Initial base saturation & - & HWSD \\
\hline Cpool_0 & Initial amount of $C$ per unit area & $\mathrm{g} \mathrm{m}^{-2}$ & HWSD \\
\hline CNrat_0 & Initial C:N ratio in topsoil & - & DSMW $^{5}$ \\
\hline TempC & Average (soil) temperature & ${ }^{\circ} \mathrm{C}$ & $\mathrm{CMA}^{6}$ \\
\hline Theta & Water content of the soil & $\mathrm{m}^{3} \mathrm{~m}^{-3}$ & MetHyd $^{7}$ \\
\hline percol & Precipitation surplus & $\mathrm{m} \mathrm{yr}^{-1}$ & MetHyd \\
\hline \multicolumn{4}{|c|}{ Model parameters } \\
\hline $\mathrm{KCO}_{2}$ & $\begin{array}{l}\text { Equilibrium constant for } \mathrm{CO}_{2} \\
\text { dissociation }\end{array}$ & $\mathrm{mol}^{2} \mathrm{l}^{-2} \mathrm{bar}^{-1}$ & Default \\
\hline Korg & $\begin{array}{l}\text { Constant for organic anion } \\
\text { dissociation }\end{array}$ & $\mathrm{mol} \mathrm{l}^{-1}$ & $\begin{array}{l}\text { Posch and } \\
\text { Reinds (2009) }\end{array}$ \\
\hline rf_min & $\begin{array}{l}\text { Reduction factor of mineralization } \\
\text { rates }\end{array}$ & - & MetHyd \\
\hline rf_nit & Reduction factor of nitrification rates & - & MetHyd \\
\hline rf_denit & $\begin{array}{l}\text { Reduction factor of denitrification } \\
\text { rates }\end{array}$ & - & MetHyd \\
\hline $\operatorname{lgKAlBC}$ & $\log _{10}$ of Al-BC exchange constant & - & $\begin{array}{l}\text { De Vries and } \\
\text { Posch (2003) }\end{array}$ \\
\hline $\operatorname{lgKHBC}$ & $\log _{10}$ of H-BC exchange constant & - & $\begin{array}{l}\text { De Vries and } \\
\text { Posch (2003) }\end{array}$ \\
\hline lgKAlox & $\log _{10}$ of $\mathrm{Al}$ equilibrium constant & - & $\begin{array}{l}\text { De Vries and } \\
\text { Posch (2003) }\end{array}$ \\
\hline $\mathrm{PO}_{\text {admax }}$ & Maximum $\mathrm{P}$ adsorption capacity & meq kg ${ }^{-1}$ & Jia (2011) \\
\hline $\mathrm{PO}_{4}$ half & $\begin{array}{l}\text { Constant of half-saturation adsorption } \\
\text { capacity of P }\end{array}$ & meq $\mathrm{l}^{-1}$ & Jia (2011) \\
\hline
\end{tabular}




\begin{tabular}{|c|c|c|c|}
\hline SO4 $4_{\text {admax }}$ & Maximum S adsorption capacity & meq kg-1 & Neglected $^{8}$ \\
\hline $\mathrm{SO}_{\text {half }}$ & $\begin{array}{l}\text { Constant of half-saturation adsorption } \\
\text { capacity of S }\end{array}$ & meq $\mathrm{l}^{-1}$ & Neglected \\
\hline \multicolumn{4}{|c|}{ Meteorological data } \\
\hline Temperature & Monthly averaged temperature & ${ }^{\circ} \mathrm{C}$ & CMA \\
\hline Precipitation & Monthly averaged Precipitation & $\mathrm{mm}$ & CMA \\
\hline Sunshine & Monthly averaged sunshine hours & $\mathrm{h}$ & CMA \\
\hline Clay_ct & Clay content in the soil & $\%$ & HWSD \\
\hline Sand_ct & Clay content in the soil & $\%$ & HWSD \\
\hline
\end{tabular}

${ }^{1}$ denotes the ion $\mathrm{NH}_{\mathrm{x}}, \mathrm{NO}_{\mathrm{y}}, \mathrm{SO}_{\mathrm{x}}, \mathrm{P}, \mathrm{K}, \mathrm{Na}, \mathrm{Ca}, \mathrm{Mg}, \mathrm{HCO}_{3}, \mathrm{Al}$ and $\mathrm{H} ;{ }^{2} \mathrm{Zhu}$ et al. (submitted) gives data on both fertilizer input (using data from the National Bureau of Statistics of China; NBSC) and deposition (using data from a series references); ${ }^{3}$ Root zone used in the research was $0.3 \mathrm{~m} ;{ }^{4}$ HWSD, Harmonized World Soil Database (version 1.1); ${ }^{5}$ DSMW, The Digital Soil Map of the World; ${ }^{6}$ CMA, China Meteorological Administration; ${ }^{7}$ means that the data were derived by running the model MetHyd; ${ }^{8} \mathrm{SO}_{4}$ adsorption was neglected, i.e. $\mathrm{SO}_{4}$ admax and SO4 $4_{\text {half }}$ were set to zero.

2.3 Calculation of times to deplete calcium carbonate pools

For calcareous soil, we only calculated the years to deplete the calcium carbonate pool $\left(\mathrm{Pool}_{c}\right)$ due to its strong neutralizing capacity against acidification (De Vries et al., 1989). The years of depletion were calculated as $\mathrm{Pool}_{c}$ divided by the average acidification rate during the period 2010-2050. Pool $_{c}\left(\mathrm{keq}^{\mathrm{h}} \mathrm{H}^{-1}\right)$ was calculated as:

$$
\text { Pool }_{c}=C_{C a C O 3} \times B D \times T \times 10^{5} / 50
$$

Where $\mathrm{C}_{\mathrm{CaCO}}$ is the weight-percent concentration of calcium carbonate in soil 
(weight-\%); $B D$ and $T$ denote the soil bulk density $\left(\mathrm{g} \mathrm{cm}^{-3}\right)$ and depth of root zone (m; $0.3 \mathrm{~m}$ was used in our assessment). The multiplication of $10^{5}$ and the division of 50 were needed to derive the equivalent unit "keq ha-1" on the basis of the molecular weight of $\mathrm{CaCO}_{3}$ and the charge 2 of $\mathrm{Ca}^{2+}$ after (potential) dissolution.

The total acidification rate $\left(H_{t o t}\right)$ was quantified by the net losses of $\mathrm{BC}$, as:

$$
H_{\text {tot }}=B C_{l e}+B C_{\text {rem }}-B C_{\text {in }}
$$

Where, $B C_{l e}$ and $B C_{\text {rem }}$ denote the base cation losses from root zone by leaching and crop removal and $B C_{\text {in }}$ denotes the total base cation inputs from fertilizer, deposition and manure. The leaching losses of BC were derived with VSD+, accounting for both the net loss of $\mathrm{BC}$, mainly associated with nitrate leaching due to fertilization (human-induced acidification) and with natural acidification (dissociation of $\mathrm{CO}_{2}$ ).

\subsection{Scenario design}

The expected population in China is peaking at 2030, while the food demand will keep growing afterwards (Jiao et al., 2016; Ma et al., 2013). The demand at 2050 is forecasted twice that of 2005 due to economic growth and diet transition (Tilman et al., 2011; Valin et al., 2014). Due to the positive relationship between the $\mathrm{N}$ fertilizer application, food production and cropland acidification (Guo et al., 2010), we focus on predicting that acidification during the future period 2010-2050. In order to mitigate soil acidification in the future, several scenarios were designed including possible changes of fertilizer consumption, manure utilization and field management on the 
basis of national policy. In this case, changes of major element inputs and outputs in croplands (i.e. fertilizer, manure and crop removal) are considered, while changes in deposition are neglected in future. The designed scenarios are described below.

(I) Business as usual (BAU): 1\% increase of $\mathrm{N}$ fertilizer application per year after 2010 up to 2050.

(II) No N fertilizer increase after 2020 (N2020): As with the BAU scenario, the $\mathrm{N}$ application rate is assumed to increase by 1\% in the period 2010-2020 and kept constant afterwards in the period 2020-2050. This scenario is in line with the policy of no increase in fertilizer consumption after 2020 (Ministry of Agriculture of China, 2015).

(III) Replacement of chemical N fertilizer by Manure (30\%MR): As with BAU, a 1\% N fertilizer input increase is assumed during 2010-2050 but after 2010, 30\% of the synthetic $\mathrm{N}$ fertilizer input is replaced by animal manure. This implies an enhanced BC input, since manure contains significant amounts of base cations.

(IV)100\% crop residues return to cropland (100\%RR): In this scenario, the $\mathrm{N}$ fertilizer input is equal to BAU, but the proportion of crop residues return increases from the current percentage in 2010 (39.6\% of wheat, $54.7 \%$ of maize and $59.3 \%$ of rice, Zhu et al. (submitted)) to $100 \%$ in 2020 and kept at that level afterwards.

(V) Integrated N2020, manure replacement and crop residues return (INMR): In this combined scenario, the future $\mathrm{N}$ inputs are kept constant after 2020 (equal to N2020), 
but $30 \%$ of the synthetic $\mathrm{N}$ fertilizer input is replaced by animal manure after 2010 (30\%MR) and straw return increases to 100\% between 2010 and 2020 (100\%RR). The integrated scenario INMR was designed to evaluate the combined effects of reduced $\mathrm{N}$ input by no increase in fertilizer use after 2020, increasing BC input by manure and reducing BC removal by crop residues on soil acidification.

We assumed in all scenarios that the $\mathrm{N}$ fertilizer types used in the future are consistent with their use in the period $2005-2010$, i.e. $14 \%$ of $\mathrm{N}$ as $\mathrm{NH}_{4} \mathrm{HCO}_{3}, 5 \%$ as $\mathrm{NH}_{4} \mathrm{Cl}$ and the rest being urea (treated as $\mathrm{NH}_{4} \mathrm{NO}_{3}$ in terms of proton production). Crop yields were assumed to increase at the same trends as averaged over the period 1980-2010 in all scenarios, i.e. $1.68 \%$ per year for wheat, $0.86 \%$ per year for maize and $0.71 \%$ per year for rice (Ray et al., 2013). Note that this assumes an increase in nitrogen use efficiency (NUE) in the N2020 and INMR scenario.

\section{Results}

\subsection{Element inputs and uptake}

During the period 1980-2010, the overall average $\mathrm{N}$ fertilizer application rate in the four typical cropping systems (M, W-M, W-R and R-R) increased from $8.6 \mathrm{keq} \mathrm{ha}^{-1} \mathrm{yr}^{-1}$ to $18.8 \mathrm{keq} \mathrm{ha}^{-1} \mathrm{yr}^{-1}$. Assuming a $1 \%$ increase in $\mathrm{N}$ application rates in the future (2010-2050) thus leads to an average $\mathrm{N}$ application rate near $26.4 \mathrm{keq} \mathrm{ha}^{-1} \mathrm{yr}^{-1}$ in 2050 
in the BAU scenario. When applying the policy of No Increase of Fertilizer consumption after 2020 (N2020), the averaged N application rate would stabilize at 20.7 keq ha ${ }^{-1} \mathrm{yr}^{-1}$ in 2020 (and stay constant thereafter). Separate $\mathrm{NH}_{\mathrm{x}}-\mathrm{N}$ and $\mathrm{NO}_{\mathrm{y}}-\mathrm{N}$ inputs, calculated by subtracting $\mathrm{NH}_{3}$ emissions from $\mathrm{N}$ fertilizer and $\mathrm{N}$ manure, are shown in Fig. 2. 

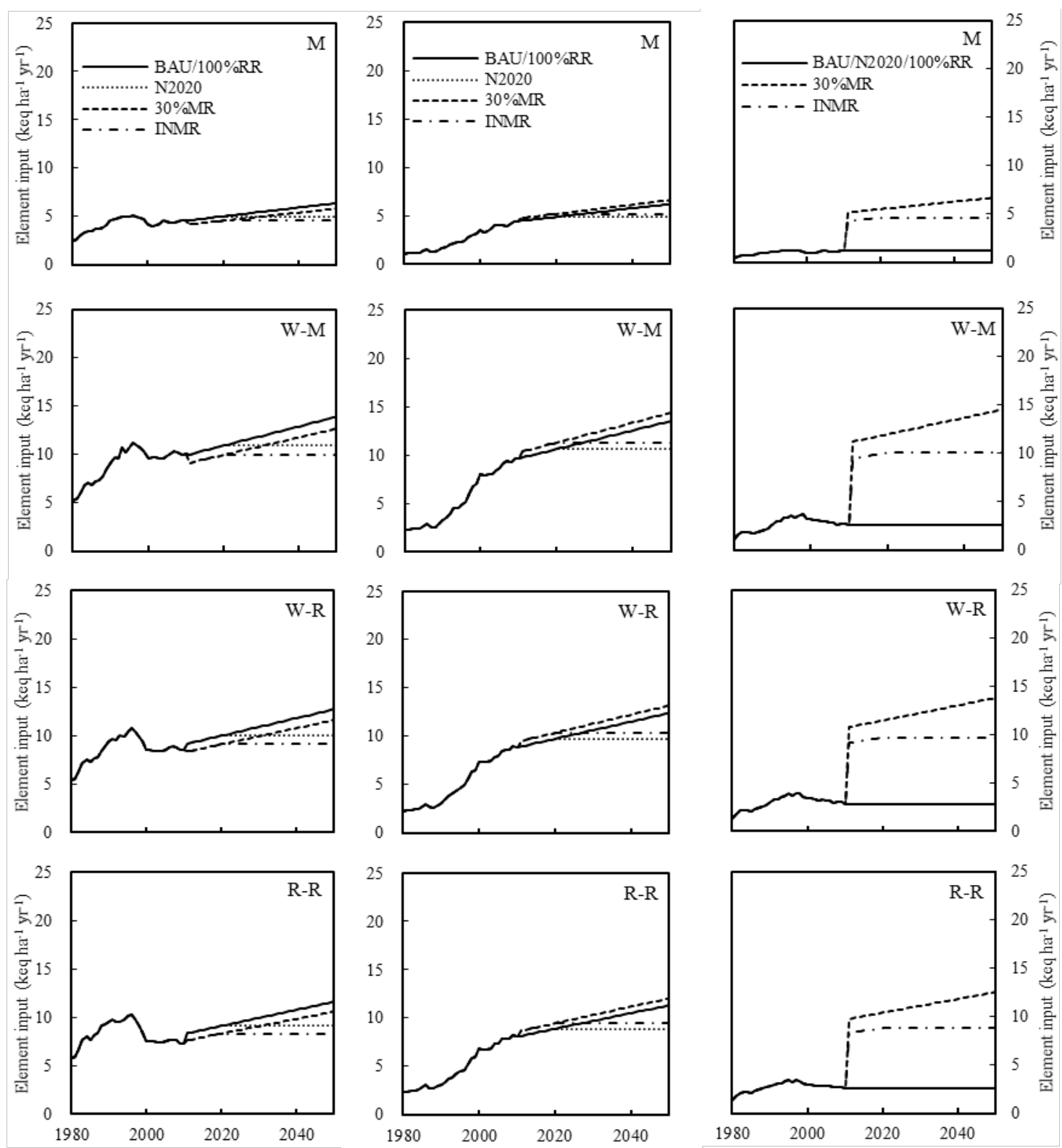

Fig. 2 Element inputs of $\mathrm{NH}_{\mathrm{x}}-\mathrm{N}$ (left), $\mathrm{NO}_{\mathrm{y}}-\mathrm{N}$ (middle) and base cations (BC, right) by fertilizer and manure for the five scenarios in the four cropping systems, i.e. maize (M, top), wheat-maize (W-M second row), wheat-rice (W-R, third row) and rice-rice (R-R, bottom). Note the small gap in $\mathrm{NH}_{\mathrm{x}}-\mathrm{N}$ and $\mathrm{NO}_{\mathrm{y}}-\mathrm{N}$ inputs between $\mathrm{BAU}$ and $30 \% \mathrm{MR}$, even though total $\mathrm{N}$ inputs are the same, because $\mathrm{NH}_{3}$ emission fractions in chemical fertilizer and manure differ (see Table S1 in Supplementary material). This difference 
also occurs between N2020 and INMR.

The enormous increase in chemical $\mathrm{N}$ fertilizer inputs boosted crop yield between 1980 and 2010, which is reflected in an average total N uptake at 2010 (12.2 keq ha ${ }^{-1}$

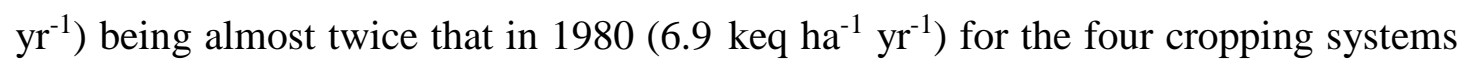
(Fig. 3).
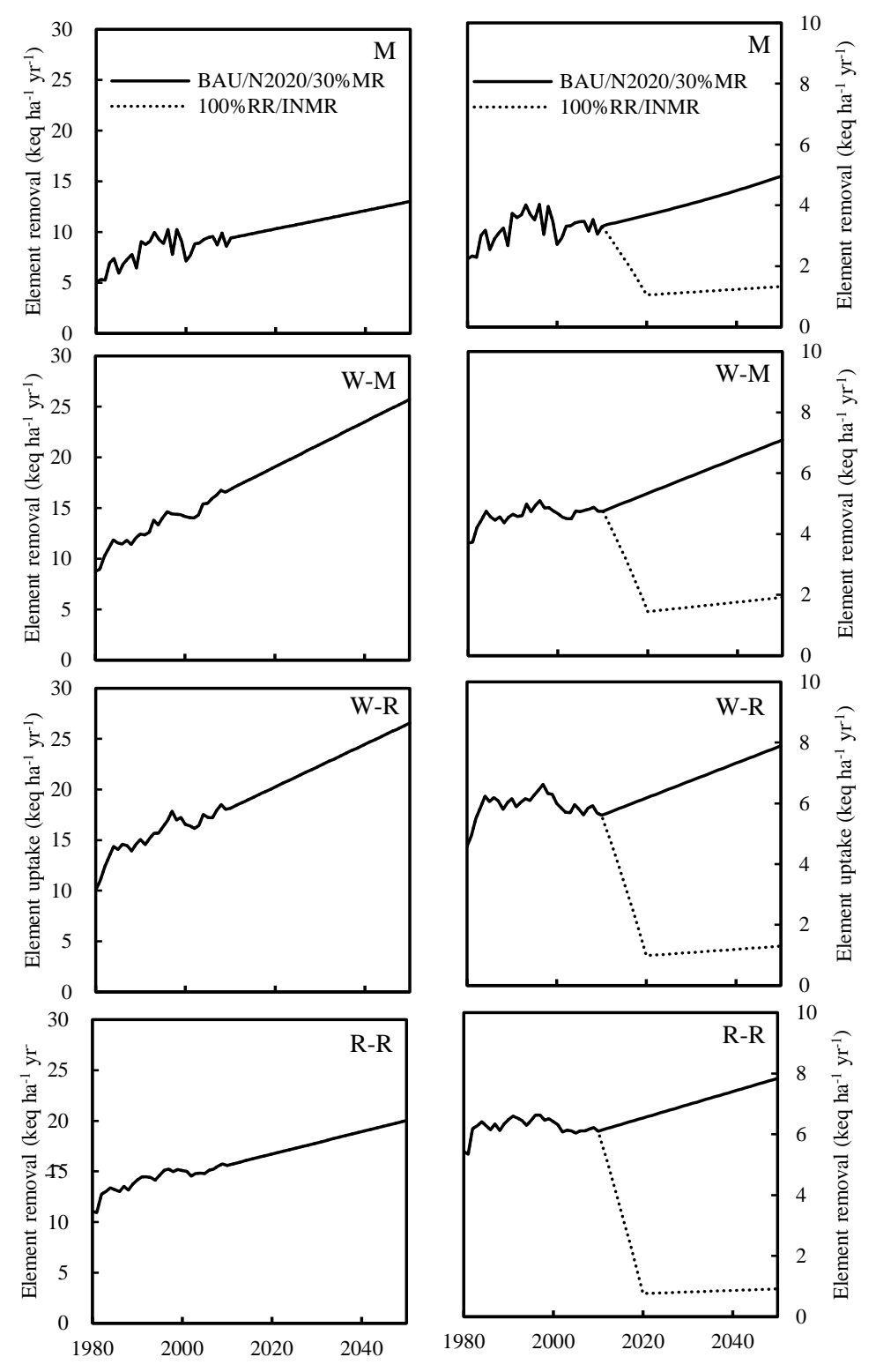

Fig. 3 Element removal of N (left) and base cations (BC, right) for the five scenarios of 
the considered four cropping systems. Note that total $\mathrm{N}$ uptake is similar in all scenarios while BC uptake changes with increased crop residue return.

However, the $\mathrm{N}$ fertilizer use efficiency (calculated as total $\mathrm{N}$ uptake divided by chemical fertilizer $\mathrm{N}$ rate) declined from 1.0 to 0.8 during 1980-2010, implying an increased $\mathrm{N}$ surplus (the difference between $\mathrm{N}$ fertilizer input and $\mathrm{N}$ crop removal) and potential $\mathrm{N}$ leaching, which also drives the BC leaching from soil.

Soil acidification, induced by base cations (BC, i.e. $\mathrm{K}^{+}, \mathrm{Na}^{+}, \mathrm{Ca}^{2+}, \mathrm{Mg}^{2+}$ ) losses from soil, is also caused by the net removal of base cations in grain yield and removed straw. There was an increased BC removal from 4.0 to $4.9 \mathrm{keq} \mathrm{ha}^{-1} \mathrm{yr}^{-1}$ by harvesting during 1980-2010 (Fig. 3). As a consequence, net depletion of the soil BC pool (0.3 and 0.1 keq ha ${ }^{-1} \mathrm{yr}^{-1}$ in 1980 and 2010) was found in all the four cropping systems, despite the inputs of base cations (BC, i.e. $\mathrm{K}^{+}, \mathrm{Na}^{+}, \mathrm{Ca}^{2+}, \mathrm{Mg}^{2+}$ ) increased from 3.7 to $4.8 \mathrm{keq} \mathrm{ha}^{-1}$ $\mathrm{yr}^{-1}$ during the period. Furthermore, this depletion of soil BC pool up to $2.7 \mathrm{keq} \mathrm{ha}^{-1} \mathrm{yr}^{-1}$ in 2050 under the BAU and N2020 scenarios since the increased BC removal up to 6.9 keq $\mathrm{ha}^{-1} \mathrm{yr}^{-1}$ in 2050. However, the BC pool can be replenished by replacing chemical fertilizer by manure. The predicted BC inputs increased strongly to $13.4 \mathrm{keq} \mathrm{ha}^{-1} \mathrm{yr}^{-1}$ in the 30\%MR scenario for the four cropping systems in 2050 (Fig. 2). Thus, the BC pool shifted from a deficit in the 1980-2010 to a surplus (6.5 keq ha $\left.{ }^{-1} \mathrm{yr}^{-1}\right)$ in 2050 under $30 \% \mathrm{MR}$. In the $100 \% \mathrm{RR}$ scenario, depletion of the soil BC pool is also reduced due to increasing straw return. Compared to BAU, the net removal of BC decreases from 6.9 
keq ha ${ }^{-1} \mathrm{yr}^{-1}$ to $1.4 \mathrm{keq} \mathrm{ha}^{-1} \mathrm{yr}^{-1}$ in the year 2050 (Fig. 3). Finally, an integrated strategy of reducing BC removal (1.4 keq ha ${ }^{-1} \mathrm{yr}^{-1}$ ) and increasing BC input (9.9 keq ha ${ }^{-1} \mathrm{yr}^{-1}$ ), i.e. INMR, increased the BC surplus up to $8.5 \mathrm{keq} \mathrm{ha}^{-1} \mathrm{yr}^{-1}$ in 2050. Note that INMR has less $\mathrm{BC}$ input than $30 \% \mathrm{MR}$, which is due to the lower $\mathrm{N}$ fertilizer use after 2020 (stabilized N fertilizer use after 2020) in INMR than in 30\%MR (continuous increased $\mathrm{N}$ fertilizer use) and the fixed replaced proportion of $\mathrm{N}$ fertilizer by manure in them.

3.2 Times to deplete the carbonate pools of calcareous soils

For calcareous soils, we calculated the time period until the pool of calcium carbonate $\left(\mathrm{CaCO}_{3}\right)$ is depleted under all five scenarios (Table 4). Results showed that the $\mathrm{CaCO}_{3}$ pool lasts for at least 150 years in the worst situation, i.e. the combination rice-rice on an Anthrosol (R-R-AT), and up to more than 5000 years in the combination of maize on a calcareous Cambisol (M-CM-Ca). Generally, the period to deplete the pool of $\mathrm{CaCO}_{3}$ among cropping systems increased from R-R (197) < W-R (267) < W-M (653) < M (1594). The depletion time among soil types increased from AT (228) < FL (624) < CM-Ca (963), even though the $\mathrm{CaCO}_{3}$ pools of Fluvisols (FL) and Anthrosols (AT) are almost twice as high as those of calcareous Cambisols (CM-Ca). This is due to the stronger acidification rates in the south (W-R and R-R cropping systems) than in the north ( $\mathrm{M}$ and $\mathrm{W}-\mathrm{M}$ cropping systems) of China. The evaluation indicates, however, that the acidification of calcareous soils is not a pressing issue in the near future. 
Table 4 Depletion periods per scenario for calcareous soils with typical cropping systems

\begin{tabular}{|c|c|c|c|c|c|c|c|c|}
\hline \multirow[t]{2}{*}{$\begin{array}{l}\text { Cropping } \\
\text { systems }\end{array}$} & \multirow[t]{2}{*}{$\begin{array}{l}\text { Soil } \\
\text { types }\end{array}$} & \multicolumn{2}{|c|}{$\begin{array}{l}\text { Poolc }_{C} \\
\text { keq ha }^{-1}\end{array}$} & \multicolumn{5}{|c|}{$\begin{array}{c}\text { Depletion years after } 2010^{2} \\
\mathrm{yr}\end{array}$} \\
\hline & & $1980^{1}$ & 2010 & BAU & N2020 & $100 \% R R$ & $30 \% \mathrm{MR}$ & INMR \\
\hline $\mathrm{M}$ & $\begin{array}{c}\mathrm{CM}- \\
\mathrm{Ca}\end{array}$ & 4012 & 3842 & 473 & 513 & 603 & 920 & 5463 \\
\hline W-M & $\begin{array}{c}\text { CM- } \\
\mathrm{Ca}\end{array}$ & 4012 & 3748 & 229 & 255 & 264 & 468 & 443 \\
\hline W-M & FL & 7952 & 7608 & 588 & 636 & 722 & 1572 & 1348 \\
\hline W-R & FL & 7952 & 7031 & 236 & 239 & 267 & 312 & 319 \\
\hline W-R & $\mathrm{AT}$ & 7198 & 6310 & 220 & 224 & 251 & 298 & 304 \\
\hline $\mathrm{R}-\mathrm{R}$ & AT & 7198 & 6095 & 174 & 174 & 199 & 215 & 223 \\
\hline
\end{tabular}

${ }^{1}$ Pool $_{C}$ denotes the acid neutralizing pool by calcium carbonate that in the top $0.3 \mathrm{~m}$ soils; ${ }^{2}$ calculated as the $\mathrm{Pool}_{C}$ divided by the average acidification rate during the period 2010-2050.

3.3 Changes in base saturation and $\mathrm{pH}$ of the non-calcareous soils

In contrast to the acid-insensitive calcareous soils, non-calcareous soils showed obvious acidification, illustrated by a rapid decline in both soil BS (base saturation) and $\mathrm{pH}$ (Fig. 4). 

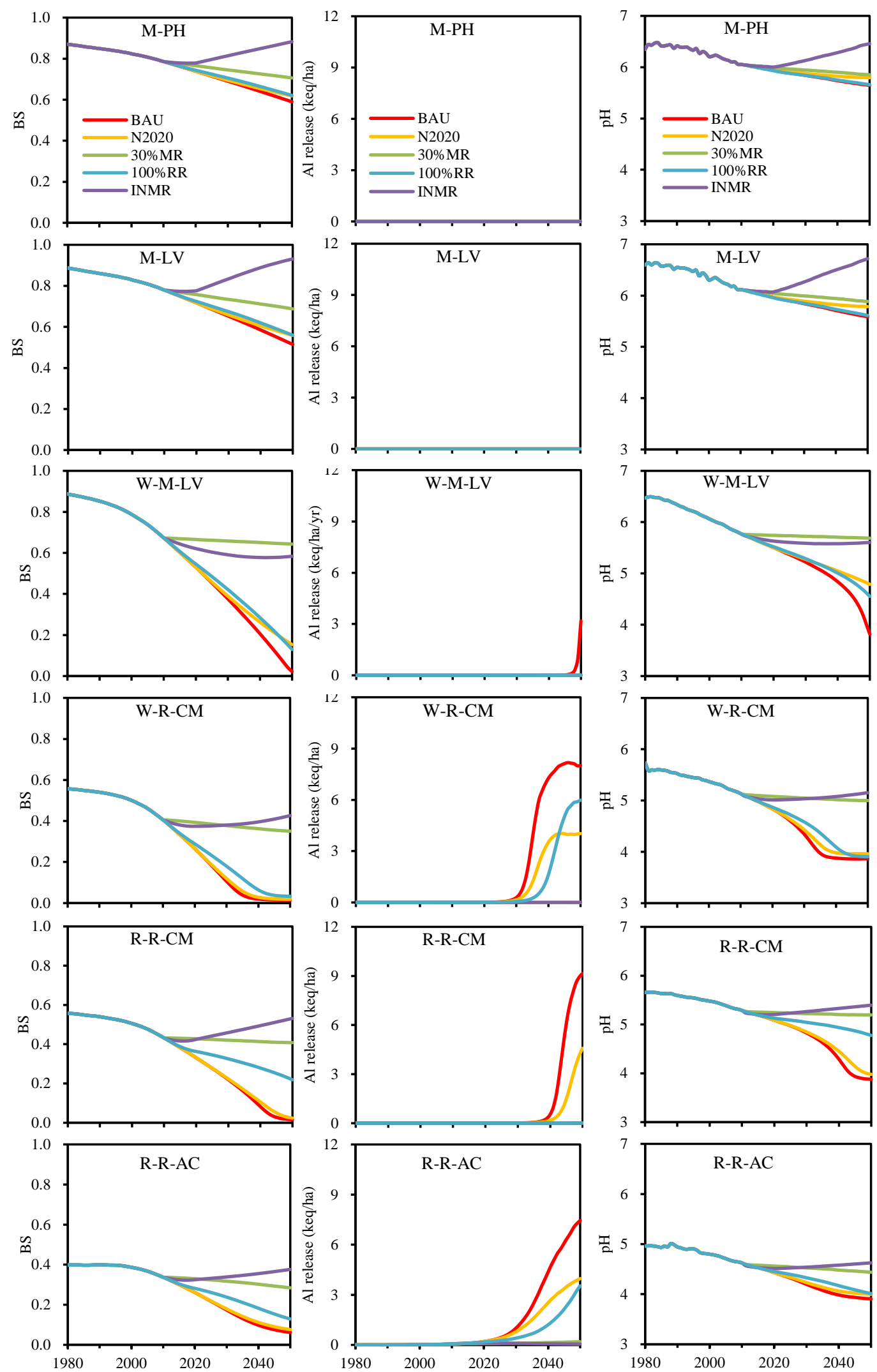

Fig. 4 Predicted changes in soil base saturation (BS, left) aluminum release (middle) 
and $\mathrm{pH}$ (right) for the six combinations of non-calcareous soils and cropping systems in the period $1980-2050$.

For the combination of maize on Phaeozems (M-PH), the worst acidification occurred under the BAU scenario, with a decline of 28\% in BS during 1980-2050 and a corresponding decline of $0.7 \mathrm{pH}$ units. Comparable trends were predicted for the scenarios N2020 and 100\%RR. When applying the 30\%MR scenario, the acidification was much less due to a strongly reduced BS decline. Finally, under the INMR scenario, we predicted an acidification recovery, i.e. soil BS and $\mathrm{pH}$ increased after 2018. The combination of maize on Luvisol (M-LV) showed similar trends as M-PH, but a slightly stronger decline in soil BS and pH in the BAU, N2020, 30\%MR and 100\%RR scenarios. For example, the decrease in soil BS and pH between 1980 and 2050 was predicted at 0.37 and 1.0 units under BAU scenario, as compared to 0.28 and 0.7 units for M-PH.

By contrast to the single maize cropping system, the wheat-maize combination on Luvisol (W-M-LV) exhibited a much stronger acidification. A rapid exhausting of BS and a sharp decline of $\mathrm{pH}$ from 6.5 to 3.8 occurred in the period 1980-2050 under the BAU scenario, associated with an elevated release of Al after the year 2045. The predictions for the N2020 and 100\%RR scenarios showed less acidification than the BAU scenario, reflected by significantly reduced Al release. However, 30\%MR and INMR are the best practices to alleviate soil acidification, although BS still declined 
to 0.64 and 0.58 in 2050 , respectively.

Similarly, W-R is also a cropping system for which we predicted a strong acidification, with BS changing from 0.56 in 1980 to being almost exhausted in 2050 under the BAU scenario, accompanied by a corresponding $\mathrm{pH}$ decrease from 5.6 to 3.9. The N2020 and $100 \%$ RR scenarios showed quite similar results, except for a lower $\mathrm{Al}$ release as compared to $\mathrm{BAU}$. The $30 \% \mathrm{MR}$ can effectively restrain $\mathrm{Al}$ release by keeping a relative high $\mathrm{pH}$ during the simulation period. However, a slight acidification recovery was predicted in the optimal scenario INMR after 2010. The soil BS and pH increased from 0.41 and 5.1 in 2010 to 0.43 and 5.2 in 2050 in INMR, respectively.

Similar to W-R-CM, the predictions for the combination of R-R-CM also resulted in a dramatic acidification. For example, a dramatic Al released was found in the BAU and N2020 scenarios after 2040, associated with a pH decline below 4.5. The $100 \%$ RR can significant reduce the Al release as compared to BAU and N2020, indicating an effective way to alleviate acidification. The $30 \% \mathrm{MR}$ and INMR can obviously mitigate the acidification, reflected by a BS of 0.41 and 0.53 and a pH over 5.0 in 2050. Furthermore, acidification recovery is also predicted after 2019 under INMR, with the soil BS and pH rising from 0.42, 5.2 to 0.53 and 5.4, respectively.

In R-R-AC, the Al release is predicted earlier (at 2030) in the BAU, N2020 and 100\%RR scenarios, compared to R-R-CM, associated with a soil pH below 4.5. While, 
30\%MR and INMR can significantly mitigate soil acidification, keeping the BS greater than 0.2 and $\mathrm{pH}$ around 4.5. A very slow recovery is also predicted under INMR, with the pH increase from 4.5 in 2020 to 4.6 in 2050.

Overall, scenarios of INMR and 30\%MR are predicted to be most effective strategies in alleviating acidification, but acidification recovery was only predicted for the M, W-R and R-R cropping systems under INMR. The N2020 and 100\%RR scenarios can only slightly reduce the acidification, reflected by similar trends of BS and $\mathrm{pH}$ decline as compared to BAU.

\section{Discussion}

4.1 Different acidification rates between soil types and cropping systems

In this study, we assessed the acidification of typical cropping systems for the period 1980-2050. The averaged $\mathrm{pH}$ decrease for all soil-crop combinations was 0.44 units during the period 1980-2010, which is comparable with the reported results of 0.50 units by Guo et al. (2010) during 1980s to 2000s, which implies that the model results are plausible. The validity of the extended model VSD+ to simulate the $\mathrm{pH}$ for agricultural ecosystems also follows from a previous study showing a good comparison of model results with long-term experimental data (Zeng et al., 2017).

Our results indicate that non-calcareous soils are sensitive to acidification, reflected by rapid BS and pH decreases during the period 1980-2050 (Fig. 4). By contrast, 
calcareous soils are insensitive and the $\mathrm{CaCO}_{3}$ system can buffer the incoming acidity for more than 150 years in most combinations (Table 4). The reason is that the acid-neutralizing pool of calcareous soil by $\mathrm{CaCO}_{3}\left(4012-7952 \mathrm{keq} \mathrm{ha}^{-1}\right.$, Table 4$)$ is much greater than that of non-calcareous soils by exchangeable BC (286-726 keq $\mathrm{ha}^{-1}$ ), which is obtained by multiplying the CEC with the BS, bulk density and soil depth of $0.3 \mathrm{~m}$. Our results are consistent with the results of a constant acid load of 5 keq $\mathrm{ha}^{-1} \mathrm{yr}^{-1}$ under different buffer systems by De Vries et al. (1989), and with the large scale pH changes across China in the period 1980-2005 (Guo et al., 2010). This explains why almost all acidification related research focuses on non-calcareous soils (e.g. (Fujii et al., 2009; Goulding, 2016; Mao et al., 2017)).

Soil acidification is mainly driven by nitrogen (nitrate) induced base cation leaching, and the net removal of base cations by harvest (Duan et al., 2004; Guo et al., 2010). The effect of acidification rates on soil $\mathrm{pH}$, base saturation and ultimately $\mathrm{Al}$ release is further affected by differences in CEC and base saturation. Among non-calcareous soils, the acidification rates thus differed (Fig. 5), due to the differences in soil characteristics and cropping systems (i.e. crop type and field management). For example, even though similar N, BC inputs and uptake for the cropping system R-R occurred on Cambisols (CM) and Acrisols (AC), the rather comparable inputs and outputs caused different effects in terms of changes in soil pH and $\mathrm{Al}$ release at 2050. These differences were mainly due to differences in the initial 
CEC and BS (Table S4 in Supplementary material), which determines the buffering capacity to acid inputs in these soils (De Vries et al., 1989). Furthermore, the differences in de-nitrification and the subsequent $\mathrm{N}$ leaching, as affected by $\mathrm{pH}$ and soil physical characteristics, also contributed to the differences (Bonten et al., 2016; Kim et al., 2016; Xue et al., 2016). In our simulations, soil acidification reduces denitrification, thus enhancing $\mathrm{N}$ leaching. In combination with the high $\mathrm{BC}$ removal by grains and crop residues, this explains the predicted decrease of $\mathrm{pH}$ values, even in rice-rice combinations. Such low $\mathrm{pH}$ values have, however, also been observed in field situations for rice (Zhu et al., 2016).
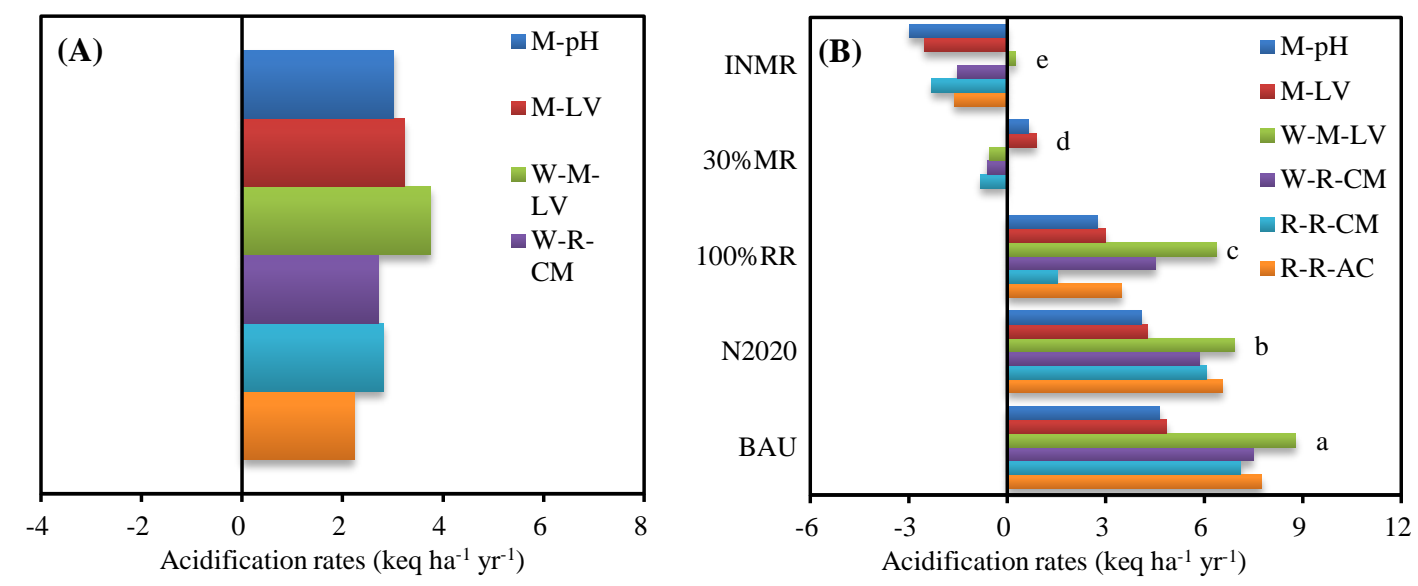

Fig 5. Predicted average net proton production for the six combinations of soils and cropping systems during 1980-2010 (A) and for 2011-2050 (B) in response to the different scenarios. The different lowercase letters next to the bars in (B) denote the significant difference $(P<0.05)$ between the combinations. 
In addition, field management and crop types also have effects on soil acidification. For example, different $\mathrm{pH}$ decreases among four rotations were reported in a 14-year long-term trial in South Australia (Xu et al., 2002). The fundamental reason is that disturbed element input-output budgets by fertilization and vegetation removal influence the proton production and consumption (De Vries and Breeuwsma, 1987; Fujii et al., 2009). By referring to the calculation on proton production-consumption described by De Vries and Breeuwsma (1987), we further assessed the acidification rates among the 6 combinations under non-calcareous soils (Fig. 5). The results showed that W-M cropping system has the greatest acidification rates (3.8 keq ha ${ }^{-1}$ $\mathrm{yr}^{-1}$ ), followed by the M (3.1 keq ha-1 $\left.\mathrm{yr}^{-1}\right), \mathrm{W}-\mathrm{R}\left(2.7 \mathrm{keq} \mathrm{ha}^{-1} \mathrm{yr}^{-1}\right)$ and R-R (2.5 keq $\mathrm{ha}^{-1} \mathrm{yr}^{-1}$ ) during 1980-2010.

In summary, the joint effects of differences in soil properties, field management and crop types lead to different soil acidification rates and related differences in the changes of BS and $\mathrm{pH}$.

\subsection{Effects of different scenarios in reducing soil acidification}

Liming has been widely recommended to manage soil acidification (Goulding, 2016; Zhu et al., 2016). However, this management approach is impractical in some areas due to supply shortages and high costs (Shi et al., 2017; Xu and Coventry, 2003). Therefore, we attempted to propose feasible strategies to mitigate the acidification authentically. In view of this, several scenarios of adjusted field management, also 
considering national policy, were designed.

Compared to BAU, the N2020 scenario, with no N fertilizer increase after 2020 was least effective, even though we assumed that crop growth keeps increasing at the same rate as in the past, implying an increase in $\mathrm{N}$ fertilizer use efficiency. The $100 \% \mathrm{RR}$ scenario, reducing the $\mathrm{BC}$ removal from soils is a more effective approach in reducing acidification rates.

However, the $30 \% \mathrm{MR}$ is much more effective than the N2020 and $100 \% \mathrm{RR}$ scenarios (Figs. 4 and 5). The N2020 and 100\%RR only reduced the net acidification rates by 16 and $47 \%$ on average, by controlling $\mathrm{N}$ input and increasing straw return, whereas 30\%MR significant reduced those rates by $82-111 \%$ by increasing BC inputs. In the $30 \%$ MR scenario, we assumed, however, that the NUE of manure is that of equal to fertilizer. This is based on results of long-term (15-yr) experiments on $\mathrm{N}$ uptake and NUE at four sites in China. These showed that application of mixed organic and inorganic $\mathrm{N}$ fertilizers resulted in more stable and significantly higher yields than application of inorganic N fertilizers alone (Duan et al., 2011). Moreover, (Li et al., 2017) found that the yield at an experimental plot in North China was higher after 30 years of manure $\mathrm{N}$ application than in case of NPK fertilization. The effects can be explained by the positive impact of manure application on the contents of soil organic carbon (SOC) and available P in the soil (Duan et al., 2011). Note, however, that when the NUE of manure would be less, e.g. 75\% of N fertilizers (Velthof et al., 2009) 
implying that more manure would have to applied to match the replaced $\mathrm{N}$ in the $30 \% \mathrm{MR}$ scenario to have the same yield, it would lead to an even higher reduction in acidification due to more BC inputs.

Finally, the integrated INMR scenarios, including both a reduction in $\mathrm{N}$ inputs (N2020), a reduction in BC removal (100\%RR) and an increase in BC inputs (30\%MR), reduced the acidification rates by $97-164 \%$, thus leading to recovery in most cases (Table 5). It should be noted that the effect of INMR was higher than the sum of the three strategies (N2020, 100\%RR and 30\%MR) in case of Maize (interaction effects of $20 \%$ and 25\%) and lower in double cropping systems (interaction effects of $-49 \%$ to $-72 \%$ ). The reason is that net $\mathrm{BC}$ inputs (BC input minus $\mathrm{NO}_{3}{ }^{-}$induced $\mathrm{BC}$ leaching loss) are different in 30\%MR and INMR, since the applied amount of manure is different. For example, the averaged BC input in maize (M) are 5.9 and $4.6 \mathrm{keq} \mathrm{ha}^{-1} \mathrm{yr}^{-1}$ during 2010-2050, while the $\mathrm{N}$ induced BC leaching losses are 1.8 and $0.3 \mathrm{keq} \mathrm{ha}^{-1} \mathrm{yr}^{-1}$ in the $30 \% \mathrm{MR}$ and INMR scenarios, respectively, which lead to lower net BC inputs in 30\%MR (4.1 keq ha-1 $\left.\mathrm{yr}^{-1}\right)$ than in INMR (4.3 keq ha-1 $\mathrm{yr}^{-1}$ ), which explains the positive interaction (Table 5). Inversely, the net average BC inputs in 30\%MR (12.6 keq ha $\left.{ }^{-1} \mathrm{yr}^{-1}\right)$ are greater than in INMR (10.1 keq $\left.\mathrm{ha}^{-1} \mathrm{yr}^{-1}\right)$, thus explaining the negative interaction in the wheat-maize (W-M) cropping system.

Table 5 Effects of scenarios on net acid production alleviation for the typical 
non-calcareous cropping systems

\begin{tabular}{ccccccc}
\hline Scenarios & \multicolumn{6}{c}{ Effect of scenarios on the reduction in acid production rate } \\
& \multicolumn{7}{c}{ in $^{1}$} \\
\cline { 2 - 7 } & M-PH & M-LV & W-M-LV & W-R-CM & R-R-CM & R-R-AC \\
\hline N2020 & 12 & 12 & 21 & 22 & 15 & 15 \\
$30 \% M R$ & 86 & 82 & 106 & 108 & 111 & 100 \\
$100 \% R R$ & 41 & 39 & 27 & 40 & 79 & 55 \\
INMR & 164 & 152 & 97 & 120 & 132 & 121 \\
Interactions $^{2}$ & 25 & 20 & -58 & -49 & -72 & -49 \\
\hline
\end{tabular}

${ }^{1}$ The effects are calculated by the averaged net proton production of BAU minus that of the certain scenario. ${ }^{2}$ The interactions are calculated by INMR minus the sum of N2020, 30\%MR, 100\%RR.

The results clearly show that the fundamental mechanism of mitigation is to enlarge the net BC input, either by raising input or reducing the output. This also explains why manure application significantly slows down the soil $\mathrm{pH}$ decrease in some long-term experiments, and the weak effect of straw return on managing acidification (Cai, 2010; Sun et al., 2015).

4.3 Threat to crop production from soil acidification in the future

Severe acidification has occurred over the past two decades in major Chinese croplands, ascribed to excessive $\mathrm{N}$ application to improve grain production to meet the increased food demand for a rapid growing population (Guo et al., 2010). For 2050, the food demand is forecasted to be twice as large as that in 2005 (Tilman et al., 2011; Valin et al., 2014). If the 1\% increase of $\mathrm{N}$ application is continuing in future, (BAU scenario), this will lead to 17.5 million ha of the considered croplands suffering 
from Al toxicity by 2050, which is $13.2 \%$ of the total croplands of China. The N2020 and $100 \% \mathrm{MR}$ scenarios can retard acidification rates to some extent, but it cannot prevent severe acidification in the future. There are still more than $10 \%$ of the total croplands threatened at 2050. While 30\%MR and INMR can succeed to avoid the soil suffering from $\mathrm{Al}$ toxicity before 2050. It should be noticed that even under the best scenario of INMR, there is still a predicted decline of soil BS and $\mathrm{pH}$ in the wheat-maize (W-M) cropping system. These results point to the necessity of improved manure and crop management to avoid soil acidification in the W-M cropping system.

\section{Conclusions}

By applying the extended VSD+ model on combinations of typical cropping systems and soil types, results indicate that acidification of non-calcareous soils may cause a drop of 1.1-2.5 pH units in all double cropping systems before 2050, associated with $\mathrm{Al}$ release. If the future $\mathrm{N}$ application rates increase at $1 \%$ without taking proper action, $13.2 \%$ of the total croplands will suffer from Al toxicity. The partial replacement of $\mathrm{N}$ fertilizer by $\mathrm{N}$ manure is a very effective strategy to manage soil acidification due to the addition of base cations, counteracting the loss of those cations. The most effective strategy is an integrated practice of no $\mathrm{N}$ fertilizer increase 
after 2020, 30\% of chemical $\mathrm{N}$ replacement by animal manure and the gradual increase of straw return to croplands up to $100 \%$ in 2020 (INMR). In this case, we predict that none of the cropland is threatened by Al toxicity before 2050, despite on-going acidification in wheat-maize cropping system.

\section{Acknowledgement}

This work was jointly supported by the Chinese National Basic Research Program (2015CB150400), National Natural Science Foundation of China (41425007 and 31421092) and Sino-Netherlands cooperative project "Impacts of nitrogen inputs on acidification of agricultural and non-agricultural lands in China" (grant 13CDP009). We also thanks Luc T.C. Bonten (Alterra, Wageningen) and Lu L (China Agricultural University) for the assistance in VSD+ modelling and providing the deposition data, respectively. 


\section{References}

Bonten LT, Reinds GJ, Posch M. A model to calculate effects of atmospheric deposition on soil acidification, eutrophication and carbon sequestration. Environmental Modelling \& Software 2016; 79: 75-84.

Cai Z. Acidification characteristics of red soil under long-term fertilization and effect factors. Thesis. Chinese Academy of Agricultural Sciences, Beijing. 2010.

Caputo J, Beier CM, Sullivan TJ, Lawrence GB. Modeled effects of soil acidification on long-term ecological and economic outcomes for managed forests in the Adirondack region (USA). Science of the Total Environment 2016; 565: 401-411.

Dai Z, Zhang X, Tang C, Muhammad N, Wu J, Brookes PC, et al. Potential role of biochars in decreasing soil acidification-A critical review. Science of The Total Environment 2017; 581-582: 601-611.

De Vries W, Breeuwsma A. The relation between soil acidification and element cycling. Water, Air, \& Soil Pollution 1987; 35: 293-310.

De Vries W, Hettelingh JP, Posch M. Critical loads and dynamic risk assessments: Nitrogen, acidity and metals in terrestrial and aquatic ecosystems. Vol 25. Dordrecht, Netherlands: Springer, 2015.

De Vries W, McLaughlin MJ. Modeling the cadmium balance in Australian agricultural systems in view of potential impacts on food and water quality. Science of the Total Environment 2013; 461: 240-257.

De Vries W, Posch M. Derivation of cation exchange constants for sand, loess, clay and peat soils on the basis of field measurements in the Netherlands. Alterra Green World Research, Wageningen, the Netherlands, 2003, pp. 50

De Vries W, Posch M, Kämäri J. Simulation of the long-term soil response to acid deposition in various buffer ranges. Water, Air, \& Soil Pollution 1989; 48: 349-390.

De Vries W, Römkens PF, Schütze G. Critical soil concentrations of cadmium, lead, and mercury in view of health effects on humans and animals. Reviews of Environmental Contamination and Toxicology. Springer, 2007, pp. 91-130.

Duan L. Study on mapping critical loads of acid deposition in China. Thesis. Tsinghua University, Beijing, China, 2000.

Duan L, Huang Y, Hao J, Xie S, Hou M. Vegetation uptake of nitrogen and base cations in China and its role in soil acidification. Science of the Total Environment 2004; 330: 187-198. 
Duan Y, Xu M, Wang B, Yang X, Huang S, Gao S. Long-term evaluation of manure application on maize yield and nitrogen use efficiency in China. Soil Science Society of America Journal 2011; 75: 1562-1573.

FAO/Unesco/ISRIC, 1990. Revised legend of the soil map of the world. World Soil Resources Report, FAO, Rome, Italy.

Fischer G, Nachtergaele F, Prieler S, Van Velthuizen H, Verelst L, Wiberg D. Global agro-ecological zones assessment for agriculture (GAEZ 2008). IIASA, Laxenburg, Austria and FAO, Rome, Italy 2008.

Fujii K, Funakawa S, Hayakawa C, Sukartiningsih, Kosaki T. Quantification of proton budgets in soils of cropland and adjacent forest in Thailand and Indonesia. Plant and Soil 2009; 316: 241-255.

Goulding K. Soil acidification and the importance of liming agricultural soils with particular reference to the United Kingdom. Soil Use and Management 2016; 32: 390-399.

Guo J, Liu X, Zhang Y, Shen J, Han W, Zhang W, et al. Significant acidification in major Chinese croplands. Science 2010; 327: 1008-1010.

Hue NV, Vega S, Silva JA. Manganese toxicity in a Hawaiian Oxisol affected by soil pH and organic amendments. Soil Science Society of America Journal 2001; 65: 153-160.

Jia X. Study on effect of soil properties on phosphorus fertilizer availability and phosphate adsorption-desorption. Thesis. Chinese Academy of Agricultural Sciences, Beijing, 2011.

Jiao X, Lyu Y, Wu X, Li H, Cheng L, Zhang C, et al. Grain production versus resource and environmental costs: towards increasing sustainability of nutrient use in China. Journal of Experimental Botany 2016: erw282.

Kim JM, Roh AS, Choi SC, Kim EJ, Choi MT, Ahn BK, et al. Soil pH and electrical conductivity are key edaphic factors shaping bacterial communities of greenhouse soils in Korea. Journal of Microbiology 2016; 54: 838-845.

Li H, Feng W, He X, Zhu P, Gao H, Sun N, et al. Chemical fertilizers could be completely replaced by manure to maintain high maize yield and soil organic carbon (SOC) when SOC reaches a threshold in the Northeast China Plain. Journal of Integrative Agriculture 2017; 16: 60345-7.

Li S, Li H, Yang C, Wang Y, Xue H, Niu Y. Rates of soil acidification in tea plantations and possible causes. Agriculture, Ecosystems \& Environment 2016; 233: 60-66. 
Liu X, Vitousek P, Chang Y, Zhang W, Matson P, Zhang F. Evidence for a historic change occurring in China. Environmental Science \& Technology 2016; 50: 505-506.

Ma L, Wang F, Zhang W, Ma W, Velthof G, Qin W, et al. Environmental assessment of management options for nutrient flows in the food chain in China. Environmental Science \& Technology 2013; 47: 7260-7268.

Mahler R, McDole R. Effect of soil pH on crop yield in northern Idaho. Agronomy Journal 1987; 79: 751-755.

Mao Q, Lu X, Zhou K, Chen H, Zhu X, Mori T, et al. Effects of long-term nitrogen and phosphorus additions on soil acidification in an N-rich tropical forest. Geoderma 2017; 285: 57-63.

Ministry of Agriculture of China. Action program of that zero increase of chemical fertilizer consumption after 2020. Communique of Chinese Ministry of Agriculture, 2015, pp. 19-23.

Mok JS, Yoo HD, Kim PH, Yoon HD, Park YC, Lee TS, et al. Bioaccumulation of heavy metals in oysters from the southern coast of Korea: assessment of potential risk to human health. Bulletin of Environmental Contamination and Toxicology 2015; 94: 749-755.

Nan W, Yue S, Li S, Huang H, Shen Y. The factors related to carbon dioxide effluxes and production in the soil profiles of rain-fed maize fields. Agriculture, Ecosystems \& Environment 2016; 216: 177-187.

Posch M, Reinds GJ. A very simple dynamic soil acidification model for scenario analyses and target load calculations. Environmental Modelling \& Software 2009; 24: 329-340.

Qi X, Vitousek PM, Liu L. Provincial food security in China: a quantitative risk assessment based on local food supply and demand trends. Food Security 2015; 7: 621-632.

Ran Y, Li X, Lu L, Li Z. Large-scale land cover mapping with the integration of multi-source information based on the Dempster-Shafer theory. International Journal of Geographical Information Science 2012; 26: 169-191.

Ray DK, Mueller ND, West PC, Foley JA. Yield trends are insufficient to double global crop production by 2050. PloS one 2013; 8: e66428.

Reinds GJ, Bonten L, Mol-Dijkstra JP, Wamelink GWW, Goedhart P. Combined effects of air pollution and climate change on species diversity in Europe: First assessments with VSD+ linked to vegetation models. In: Posch M, Slootweg J, Hettelingh J-P (eds) Modelling and Mapping of atmospherically-induced ecosystem impacts in Europe: 
CCE Status Report 2012. Coordination Centre for Effects, RIVM, Bilthoven, the Netherlands, 2012, pp. 49-61.

Shi R, Li J, Ni N, Mehmood K, Xu R, Qian W. Effects of biomass ash, bone meal, and alkaline slag applied alone and combined on soil acidity and wheat growth. Journal of Soils and Sediments 2017; 1-11. Doi:10.1007/s11368-017-1673-9

Sun R, Zhang X, Guo X, Wang D, Chu H. Bacterial diversity in soils subjected to long-term chemical fertilization can be more stably maintained with the addition of livestock manure than wheat straw. Soil Biology and Biochemistry 2015; 88: 9-18.

Tilman D, Balzer C, Hill J, Befort BL. Global food demand and the sustainable intensification of agriculture. Proceedings of the National Academy of Sciences 2011; 108: 20260-20264.

Valin H, Sands RD, van der Mensbrugghe D, Nelson GC, Ahammad H, Blanc E, et al. The future of food demand: understanding differences in global economic models. Agricultural Economics 2014; 45: 51-67.

Velthof G, Oudendag D, Witzke H, Asman W, Klimont Z, Oenema O. Integrated assessment of nitrogen losses from agriculture in EU-27 using MITERRA-EUROPE. Journal of Environmental Quality 2009; 38: 402-417.

Vitousek PM, Naylor R, Crews T, David M, Drinkwater L, Holland E, et al. Nutrient imbalances in agricultural development. Science 2009; 324: 1519-1520.

$\mathrm{Xu}$ R, Coventry DR. Soil pH changes associated with lupin and wheat plant materials incorporated in a red-brown earth soil. Plant and Soil 2003; 250: 113-119.

Xu R, Coventry DR, Farhoodi A, Schultz J. Soil acidification as influenced by crop rotations, stubble management, and application of nitrogenous fertiliser, Tarlee, South Australia. Australian Journal of Soil Research 2002; 40: 483-496.

Xue C, Zhang X, Zhu C, Zhao J, Zhu P, Peng C, et al. Quantitative and compositional responses of ammonia-oxidizing archaea and bacteria to long-term field fertilization. Scientific Reports 2016; 6: 28981.

Zeng M, De Vries W, Bonten LTC, Zhu Q, Hao T, Liu X, et al. Model-based analysis of the long-term effects of fertilization management on cropland soil acidification. Environmental Science \& Technology 2017; 51: 3843-3851.

Zhang Y, He X, Liang H, Zhao J, Zhang Y, Xu C, et al. Long-term tobacco plantation induces soil acidification and soil base cation loss. Environmental Science and Pollution Research 2016; 23: 5442-5450.

Zhou H. Effects of cropland soil acidification and remediation in Jiaodong of 
Shangdong Province. Thesis. China Agricultural University, Beijing, 2015.

Zhu H, Chen C, Xu C, Zhu Q, Huang D. Effects of soil acidification and liming on the phytoavailability of cadmium in paddy soils of central subtropical China. Environmental Pollution 2016; 219: 99-106.

Zhu Q, De Vries W, Liu X, Hao T, Zeng M, Shen J, et al. Element budgets and acidification evaluation in croplands across Chinese mainland in period 1980-2010, Submitted. 